\title{
History of Land Registration and Small House Policies in the New Temitories of the Hong Kong Special Administrative Region, the People's Republic of China
}

\author{
Philip Sing-sang Fung ${ }^{1}$ and Almond Sze-mun Lee ${ }^{2}$
}

(Received January 7, 2013 / Revised January 29, 2014 / Accepted January 29, 2014)

\begin{abstract}
Hong Kong, a well-known metropolis characterized by skyscrapers on both sides of the Victoria Harbour, consists mainly of 3 parts, namely the Hong Kong Island, the Kowloon peninsula and the New Territories (N.T.) which is the land area north of Kowloon plus a number of outlying islands. Located in the N.T. are all the new towns, market towns; and in the plains and valleys lie scattered village houses of not more than 3 storeys within the confines of well-defined village. These village houses are governed by a rural housing policy that could be traced back to the very beginning of the former British administration in the N.T. By the Convention of Peking of 1898, the N.T., comprising the massive land area north of Kowloon up to Shenzhen River and 235 islands, was leased to Britain by China for 99 years from 1st July 1898. Soon after occupation, the colonial government conducted a survey of this uncharted territory from 1899 to 1903, and set up a land court to facilitate all land registration work and to resolve disputed claims. By 1905, the Block Crown Leases with Schedule of Lessees and details of the lots, each with a copy of the lot index plan (Demarcation Plan) were executed. Based on the above, Crown rent rolls were prepared for record and rent collection purposes. All grants of land thereafter are known as New Grant lots. After completion and execution of the Block Crown Lease in 1905, N.T. villagers had to purchase village house lots by means of Restricted Village Auctions; and Building Licences were issued to convert private agricultural land for building purposes but gradually replaced by Land Exchanges (i.e. to surrender agricultural land for the re-grant of building land) from the early 1960's until introduction of the current Small House Policy in October 1972. It was not until the current New Territories Small House Policy came into effect in December 1972 that the Land Authority can make direct grant of government land or approve the conversion of self-owned agricultural land to allow indigenous villagers to build houses within the village environs under concessionary terms. Such houses are currently restricted to 700 square feet in area and three storeys with a maximum height of 27 feet. An indigenous villager is a male descendent of a villager who was the resident of a recognized village already existing in 1898. Each villager is only allowed one concessionary grant in his lifetime. Upon return of Hong Kong to the People's Republic of China on July 1st, 1997, the traditional rights of indigenous villagers are protected under Article 40 of the Basic Law (a mini-constitution of the Hong Kong Special Administrative Region). Also all N.T. leases have been extended for 50 years up to 2047. Owing to the escalating demand and spiral landed property prices in recent years, abuse of the N.T. Small House Policy has been reported in some areas and is a concern in some quarters. The Hong Kong Institute of Land Administration attempts to study the history that leads to the current rural housing policy in the New Territories with particular emphasis on the small house policy, hoping that some light can be shed on the "way forward" for such a controversial policy.
\end{abstract}

Key words: Rural Housing, Small House Policy, Basic Law, Heung Yee Kuk

Hong Kong consists mainly of three parts, namely the Hong Kong Island, the Kowloon peninsula and the New Territories (N.T.) which is the mass of land area north of Kowloon plus a number of outlying islands. By the Convention of Peking of 1898 , the N.T. comprising the land area north of Kowloon up to Shenzhen River together with 235 islands was leased to Britain by China for 99 years commencing from $1^{\text {st }}$ July 1898.

In the context of this document, Small House is defined as low rising houses of not more than 3 stories nor exceed a height of 8.23 meters and the maximum roofed-over area of the house shall not exceed 65.03 square meters developed from 1898 up to present in the N.T. of Hong Kong. As it is rather unique in Land Policy, the authors would like to discuss it under the topic "History of Land Registration in Hong Kong".

Land, according to Qing Chinese tenure was held as freehold by grant from the Qing Emperor, and inherited by males descended in the male line only. Daughters generally did not inherit ancestral properties.

Deeds of absolute sale had been brought in from the New Territories for registration which were made in the reign of

본 원고는 2012년 9월 LHI Journal에서 주최한 ‘주거복지 및 공공정책 국제컨퍼런스’에서 발표된 논문을 Research Note로 재정리한 것입니다.

1) Vice Chairman, Hong Kong Institute of Land Administration (Corresponding author: pssfunghk@gmail.com)

2) Chairman of the Public Relation Committee, Hong Kong Institute of Land Administration 
the Emperor KA TSING and of subsequent Emperors of the Ming Dynasty (A.D. 1368 to 1644) and which had been recognized by the Qing Dynasty. The registration is to enable the collection of tax from land owners.

Officially registered title deeds were called 'red deeds' because they were stamped with the official stamp in red. Private deeds of sale were called 'white deeds' because they were simply written on plain paper and did not bear the official red stamp, but the purchaser had the right to register his purchase and obtain a red deed. White deeds were merely unregistered transfers and gave very few particulars beyond the rent to be received and sometimes the amount of grain required to sow the plot and its local name.

Red deeds were the only deeds which the Qing Government took cognizance of and Government Rent was collected on these deeds only.

Where land was sold, the vendor and the purchaser would exchange a deed (the 'White Deed') which would bear the names of both parties, the witness to the transaction, the sum agreed, the location of the land, and other relevant details. The purchaser would be responsible for bringing this deed to the attention of the relevant Authorities.

The purchaser had to be a registered land tax payer with a page in his name in the Land Tax Register. Once the purchaser had satisfied the County Land Register that he was a Registered Land Tax Payer, he could claim for a Kai Mei (Memorial). These were large-size sheets, with every page being numbered sequentially and bound into archive volumes. They were printed double, and numbered between the two vertical panels of identical text. The necessary entries were entered into both copies, and the Land Registration Office seal was affixed so as to overlap both panels of text. The page was then cut down the centre, the left hand half remaining in the Land Registration Office whereas the right hand half being handed to the purchaser.

The 'White Deed' and the purchaser's half of the Kai Mei were then taken to the County Land Tax Office, to claim for a Tsap Chiu which was a statement that the new purchaser had had the new purchase added to his Land Tax record, and the vendor had had it removed from his. The Tsap Chiu would only be issued after the purchaser had paid the Transfer Tax and the first year's Land Tax. When all was paid, the Land Tax Office affixed its seal over the statement as to the sum the land had sold for in the White Deed and in the purchaser's half of Kai Mei. The Tsap Chiu was issued in triplicate: one copy was kept in the Land Tax Office (this copy was stamped with the official seal in such a manner that the seal overlapped the White Deed, and numbered so that the corresponding Land Registration Office could locate for it), and the other two copies were handed to the purchaser and the vendor (the handwritten date was positioned between these two copies, and was thus cut through when the vendor's half was given to him).

The White Deed was chopped three times, by the Land Registration Office and the Land Tax Office, and usually a forth time when the whole transaction was checked, and thus became a Red Deed.

There was no check on title or bona fides, other than the check that the person purporting to be the purchaser was a Land Tax Payer.

Upon taking over the New Territories, the British Colonial (Hong Kong) Government started a survey of the whole territory in November 1899 and accomplished the allocation and registration of all privately owned land in 1905. The work of registering claims was carried out hand in hand with that of the survey and demarcation. Disputed claims were submitted to the Land Court, which apart from its judicial function of determining all land claims also had the executive duty of making up the Crown Lease Schedules and Rent Rolls. In 1905, the Block Crown Leases each with a Schedule of Lessees and details of the lots and a copy of the lot index plan (Demarcation Plan) were executed. The Chinese deeds were registered and substituted by the grant of Crown Leases by the Hong Kong Government.

Agricultural land in the New Territories was classified as $1^{\text {st }}, 2^{\text {nd }}$ or $3^{\text {rd }}$ class, and Crown rent was assessed at $\$ 3, \$ 2$ or $\$ 1$ per acre respectively. Crown rent for building land was charged $\$ 50$ an acre, or 50 cents per annum each 0.01 acre for a small house and $\$ 100$ an acre in the more thriving villages. These rates were fixed by a proclamation of July $14^{\text {th }} 1906$ and an undertaking was given that they should not be raised.

During the survey, claimants to lots were at first given 'chi-tsai' (small slips of paper), bearing on their faces the lot number and on the back the name of the owner and description of the land in Chinese to facilitate processing the claim and registration of the lots. Upon completion of the Block Crown Lease, each owner was issued a 'chap-chiu' (certificate extract of his holdings) in 1905 to 1911.

Land throughout the New Territories was held on a lease from the Crown for 75 years from July $1^{\text {st }}$, 1898, subject to renewal for a further 24 years. By the New Territories Land Ordinance of 1903 which was merged in the New Territories Ordinance on October $28^{\text {th }} 1910$, mechanism for registering land transfer and settling disputes was provided. The District Officers acting as the authority in N.T. land matters were given very wide power in the appointment of trustees and in the settlement of land disputes.

By Letters Patent, the power to dispose of Crown land in Hong Kong was vested in the Governor, who had also been authorized by the Secretary of State to make private treaty grants or sale in his discretion. The Governor further authorized Assistant Land Officers under Government Gazette No. 191 of 1906 to grant licenses for the conversion of any ground in the New Territories demised as agricultural or garden ground into use for building purposes, and by Government Gazette No. 192 of 1906 to approve buildings on land in the New Territories held under lease from the Crown. All grants of land after the Block Crown Lease are classified as New Grant lots.

The Land Registration Ordinance enacted in 1844 provides 
for the registration of deeds, conveyances, judgments and other instruments affecting real or immovable property, the keeping of Land Registry records, and for other matters relating to land registration in Hong Kong.

It is noted that title deeds in respect of land grants and conveyance of land in the N.T. were registered as early as 1905 .

Villagers in the N.T. could buy Crown land for building houses. The earliest sale of Crown land by Public Auction in village areas in the New Territories could be traced back to December $5^{\text {th }} 1906$. Crown land was sold by auction at upset prices of one cent per square foot for building land, and from $3 / 4$ to $1 / 4$ cent per square foot for agricultural land, with Crown rent on the scale before mentioned. Lots exceeding 1,000 square feet may be sold by private treaty in districts away from railways or main roads where competition is out of question.

Rather than individual leases, standard conditions of sale, modified on the basis of the Block Crown Lease, were used for sale of Government land for building or agricultural use. They are known as the G.N. (Government Notification) Conditions. They were amended or revoked from time to time to bring in new conditions to reflect the policy adopted by the Government at the time of issue.

Houses of not more than 2 stories may be built on building land under these standard conditions, which were used until around 1960's when standard modern lease conditions replaced the old G.N. Conditions.

Restricted village auctions (also a kind of Public Auction) for sales of Government land to villagers for building village houses were administered by the District Officers sometime since 1959 and operated throughout the 1960s until 1972. However the restricted village auctions were not gazetted and only a notice was posted in the village calling for interested villagers to bid for the house site. The approval was given by the District Commissioner, N.T. on the understanding that the sale by Public Auction of a house site was primarily intended for the occupation of villagers. However, the identity of villagers who successfully bid the sale was not verified. Generally, auctions took place at the village school or open space in front of the village or ancestral hall.

Since the beginning of the lease of the N.T. there had been a practice that the male villagers would be given an once-ina-lifetime chance to build traditional village-type houses, free of premium, for their own occupation on their own agricultural land held under the Block Crown Lease in village areas, provided there were no "fung shui" (a Chinese philosophical system of harmonizing the human existence with the surrounding environment) or other objections.

In order to cope with village expansion, with effect from April 1957, each male villagers upon marriage was allowed to build a single story village-type house of maximum height of 15 feet with roofed-over area up to 700 square feet on their own agricultural land held under the Block Crown Lease, free of premium, provided there were no "fung shui" or other objections. Premium would be charged for building on New Grant lots in village areas. The premium free conversion of agricultural land for domestic housing was extended to pre-war New Grant lots after June 1960.

The New Tenitories Small House Policy is a policy approved by the Executive Council of the Hong Kong Government and has been implemented since December 1972. It is formulated to allow indigenous villagers of the New Territories to apply for permission to build for themselves during their lifetime each a small house on suitable sites within the environs of their village.

'Environs of a village' in general refers to a $300 \mathrm{ft}$. distance surrounding a recognized village where small house applications are considered. However, consideration will also be given to applications for sites within a ' $\mathrm{V}$ ' (village type development) zone in a Development Permission Area/Outline Zoning Plan, which encircles a recognized village and is larger than the 300 $\mathrm{ft}$. village environs.

A small house is basically a building in the New Territories constructed in accordance with the provisions of the Buildings Ordinance (Application to the New Territories) Ordinance, Chapter 121. The main features are that the building shall neither contain more than three stories nor exceed a height of 8.23 meters $(27 \mathrm{ft}$.) and the maximum roofed-over area of the house shall not exceed 65.03 square meters (700 sq. ft.). Under the said Ordinance, a certificate of exemption should be obtained from the District Lands Officer prior to the commencement of any building works unless plans prepared by an authorized person (an architect, an engineer or a surveyor) have been approved by the Building Authority. Similarly, the owner should apply for separate certificates of exemption for site formation works and drainage works from the District Lands Officer and shall not commence any works on site before obtaining the necessary certificates of exemption, or securing approval of plans by the Building Authority.

In the case of application for Building License or Land Exchange (Surrender and Regrant), the land under application must be registered in the applicant's name.

Application for small house grant on Government land from a villager living overseas will be refused unless the District Lands Officer is satisfied that the applicant intends to return and reside in his village. The District Lands Officer may however, consider overseas application for small house grant on private land.

An administrative fee will be levied for small house grants. A premium at a concessionary rate calculated by Government will also be charged except where Free Building Licenses are issued. For those small house sites where Government money has been spent on resumption, clearance, site formation or infrastructure such as those in a Village Extension Area, a higher premium will be imposed.

Pursuant to the provisions under the Town Planning Ordinance, Chapter 131, planning permission will have to be obtained from the Town Planning Board under Section 16 of the Ordinance for erection of small houses outside the ' $\mathrm{V}$ ' (village type development) Zones as shown on statutory plans such as Development 
Permission Area Plans and Outline Zoning Plans.

When the Town Planning Board considers planning applications for small house developments, the applications will be assessed in accordance with the "Interim Criteria for Consideration of Application for New Territories Exempted House / Small House in the New Territories. Under the Interim Criteria, the Town Planning Board will consider a range of factors, including whether the footprint of the proposed development mainly falls within the Village Environs, the amount of land available for small house development within the Village Type Development zone and whether the proposed development would cause adverse traffic, environmental, landscape, drainage, sewerage and geotechnical impacts on the surrounding areas.

Building Licenses are granted for development of small houses on private Lots. To maximize the number of small houses, it is very common that private agricultural land is divided into small parcels each fit for a 700 square feet building. Hence, development of small houses is mostly in a 'raindrop' pattern. The orientation and alignment of individual houses may not be compatible with neighboring houses. Unlike estate development which requires detailed planning to fulfill all the planning guidelines including drainage, sewage, power supply and access, small house development is exempted from such requirements. Hence a village congested with small house developments would very often encounter traffic congestion and flooding problem. In some extreme situations, residents living in small houses are not allowed to use motorways which pass through private land owned by others. Complaints of such nature have been reported on newspapers and are a headache to the Lands Department of the HKSAR government.

As village house or small house developments are restricted to the village environs of recognized villages, and the geographic area of land capable of such development is necessarily limited. The so-called right or privilege of villagers is in fact severely restricted. From the statistics provided by Lands Department to the New Territories Heung Yee Kuk (a statutory advisory body representing established interests in the New Territories), it can be seen that the great majority of small house applications were for permission to build on private agricultural land owned by villagers within $300 \mathrm{ft}$. of their village. Only very few applied for Government land, and the great majority of those who had been granted Government land did not get sites in the environs of their village. They were granted land in Village Extension Areas (VEAs), usually far away from their village.

VEAs are not the creation of the original 1972 Small House Policy, but had been added by administrative means to cater for those villagers, whose private land within the village environs of their village had been resumed by Government for public development under its statutory power of resumption or in the rare cases where the land within the artificially defined environs of a village is not suitable for building purposes. Anyway, all VEAs have now been suspended for a number of years.
It is interesting to note that the original 1972 Small House Policy also allowed non-indigenous villagers to build small houses on their private agricultural land, and that the Policy has been gradually and systematically tightened by Government to make applications by villagers more difficult. This has perhaps been the result of complaints of abuse of the policy and more cogently by the outcry and influence of those who think, though erroneously and perhaps out of jealousy, that villagers of the New Territories are benefiting unfairly from the said policy. Is this then a case of sour grapes or genuine criticism of an unfair system?

\section{Notes}

1. Legislations in connection with building of small house include Buildings Ordinance (Application to the New Territories) Ordinance (Chapter 121); Government Rent (assessment and collection) Ordinance (Chapter 515); Heung Yee Kuk Ordinance (Chapter 1097); New Territories Leases (Extension) Ordinance (Chapter 150) and etc.

2. Basic Law contributes to explain the right and interest of indigenous villagers in New Territories.

\section{References}

1. Department of Justice, Laws of Hong Kong, Department of Justice, Hong Kong Government SAR. (Retrieved from http://www.legislation. gov.hk/eng/home.htm)

2. Home Affairs Department, The Basic Law, Home Affairs Department, Hong Kong Government SAR. (Retrieved from http://www.basiclaw. gov.hk/en/basiclawtext)

3. Hong Kong Government, Government Reports on the New Territories for the Year 1899-1939.

4. Hong Kong Government, Hong Kong Annual Administration Reports, 1841-1941.

5. Lai, Lawrence Wai-chung, Daniel Chi-Wing Ho and Hing-fung Leung (2004), Change in use of Land: A Practical Guide to Development in Hong Kong, Hong Kong University Press.

6. Lands Department, How to apply for a small house grant. (Retrieved from http://www.landsd.gov.hk/en/legco/house.htm)

7. Land registry, Block Crown Lease, Land Registry, Hong Kong Government SAR. (Retrieved from http://www.landreg.gov.hk/ en/about/block.htm)

8. Legislative Council, Papers on Small House Policy, Legislative Council, Hong Kong Government SAR. (Retrieved from http:// www.legco.gov.hk)

9. Nissim, R. (1998), Land Administration and practice in Hong Kong, Hong Kong University Press.

10. Sit, Victor F.S. and Chi-man Kwong (2011), "History of the New Territories Heung Yee Kuk: From Leased Land to One Country Two Systems Hong Kong”, Joint Publishing Hong Kong. Advanced Institute for Contemporary China Studies, Hong Kong Baptist University.

11. Wong, Olga (2012, May 8), "Villagers cash in at new estate", The South China Morning Post. (Retrieved from www.scmp.com) 